\title{
MICROBIOLOGY QUALITY OF TINFOIL BARB Barbonymus schwanenfeldii FROM TEMBAT AND PETUANG RIVERS, KENYIR LAKE, MALAYSIA IN ASSOCIATION WITH NEMATODES, Cucullanus sp INFECTION
}

\author{
NURUL ULFAH KARIM*, SITI NURFARAHAIN MOHD SIDEK, NUR FARHAH SUFI, \\ SURZANNE MOHD AGOS, WAHIDAH WAHAB, MOHD IHWAN ZAKARIA AND MARINA \\ HASSAN
}

Higher Institution Centre of Excellent (HICoE), Institute of Aquaculture Tropical and Fisheries Research, Universiti Malaysia Terengganu, 21030, Kuala Nerus, Terengganu, Malaysia.

*Corresponding author: ulfah@umt.edu.my

Submitted final draft: 21 July $2020 \quad$ Accepted: 18 August 2020

http://doi.org/10.46754/jssm.2021.06.007

\begin{abstract}
The tinfoil barb (Barbonymus schwanenfeldii) is an important source of food and protein. This study observed the prevalence and mean intensity of nematode infestation in B. schwanenfeldii in rivers flowing into Kenyir Lake in Terengganu, Malaysia. . Furthermore, the microbiology quality analysis of non-infected and infected fish, in the parasite and water samples of Sungai Tembat and Sungai Petuang that flows into the lake were determined. B. schwanenfeldii were mostly infected by Cucullanus sp (Cucullanidae). Nematode prevalence from Sungai Tembat and Petuang were 3.59\% and $1.02 \%$, respectively, with mean intensities of 12.67 and 7.00. B. schwanenfeldii caught from Sungai Tembat showed no significant difference in total bacteria count in noninfected and infected fish. However, the total bacteria in nematodes showed a significantly $(p<0.05)$ higher amount compared to fish and river water samples. The total bacteria count in non-infected tinfoil barbs of Petuang river was higher, but not significantly different from infected fish and in nematodes. The total bacteria count in water samples of Petuang river was significantly $(\mathrm{p}<0.05)$ lower compared to non-infected tinfoil barb. Cucullanus sp showed a low prevalence and no significant influence on the microbiology quality in $B$. schwanenfeldii of Tasik Kenyir. The low presence of bacteria in current studies indicates a mutual relationship between the microbes, host and parasite.
\end{abstract}

Keywords: Kenyir Lake, tinfoil barb, nematode, Cucullanus sp., bacteria, fish quality.

\section{Introduction}

Tasik Kenyir (Kenyir Lake) is the largest manmade lake in Southeast Asia located in the east coast state of Terengganu, Peninsular Malaysia. It spans 36,900 ha with an average depth of $37 \mathrm{~m}$ and maximum of $145 \mathrm{~m}$ (Kamaruddin et al., 2011; Osnin \& Abdul Rahman, 2018). Kenyir Lake receives water from two main rivers; Terengganu and Terengan Rivers (Rouf et al., 2008).

The lake is a rich habitat for many fish species and locals living in the area mostly made a living from fishing and aquaculture. According to the Malaysia Fisheries Department (2019), the production of inland fisheries in 2018 was approximately 6,089 tonnes and worth RM162,788 million (approximately US\$39,606). Chong et al. (2010) listed a total of 521 freshwater fish species that inhabited the country's freshwater ecosystems. At least 38 of the species are found in Kenyir Lake, but only 17 have economic value (Zulkafli \& Ashhar, 2000).

Fish are susceptible to parasitic infections (Marcogliese, 2002). They include external parasites, such as protozoa, monogeneans and crustaceans. Internal parasites consist of digeneans, cestodes, nematodes and acanthocephalans, which may cause severe damage in large populations of fish (Tonguthai, 1997). Parasites often affect fish health by deteriorating their body condition, where infected individuals become thin and small because of stunted growth (Santaro et al., 2013). Heavily infested fish have lower body indices because the pathological effects increased with infection intensity compared with uninfected 
co-species or individuals infected with fewer parasites (Lemly \& Esch, 1984). Parasites may also cause mechanical damage (fusion of gill lamellae and tissue replacement), physiological damage (cell proliferation, immunomodulation, detrimental behaviour and altered growth) and nutritional deficiencies (limited food absorption) to the host (Barber, 2007).

Nematodes are non-segmented round worms and one of the most abundant group of metazoan organisms. Seesao et al. (2017) stated that 2,271 genera from 256 families have been identified, one third of which are from aquatic environments. These include five classes of nematodes: Adenophorea, Chromadorea, Enoplea, Nematoda and Secernenta. Shaharom (2012) stated that nematodes are numerous in wild fish in Kenyir Lake. Pseudopropletus notopteri is predominantly found in knife fish (Chitala chitala), while two other species (Rhabdochona sp. and Spinitectus sp.) are found in the beardless barb (Cyclocherillchthys apagon). The same author added that the nematode Pingus sinensis has also been identified in the giant snakehead (Channa micropeltes). Nevertheless, various researchers have found a diverse range of parasites in Kenyir Lake. Szekey et al. (2012) reported that wild caught Malaysian mahseer (Tor tombroides) from the lake are infected by the plasmodium Myxobolus tambroides. Previously, Szekey et al. (2009) also found Myxobolus sp. living in the silver shark minnow (Osteochillus hasselti), bonylip barb (O. vittatus) and tinfoil barb. Meanwhile, the salmon parasite Henneguya sp. has been found in the gills of marble goby (Oxyeleotris marmoratus) and Asian redtail catfish (Hemibagrus nemurus).

Bacteria may present as a normal or pathogenic flora in an aquatic animal. Newton et al. (2011) documented that lake bacteria is diversified, with 21 phyla, and five of them are commonly found - Proteobacteria, Actinobacteria, Bacteroidetes, Cyanobacteria and Verrucomicrobia. Ismail et al. (2016) reported that the discharge of agricultural run-off and domestic sewage into rivers may increase the waters' organic content and promote the growth of bacteria. In addition, aquaculture feed and human activities may also affect bacterial composition in rivers and trigger infection in the fishes (Marcel et al., 2013). The interaction between parasites and microorganisms is poorly understood. Stilwell et al., (2018) stated that bacteria may form symbiotic relationships as obligate mutualists or obligate pathogens, depending on the external environment, host identity, abiotic parameters and microbial community partners. Microbial symbioses play a crucial role in the host's health, development and nutrition.

The tinfoil barb is found in all around Kenyir Lake. It is a food fish that has acceptable flavour and in high demand. Despite its commercial importance, quality and nutritional aspects, little attention has been given to study the fish and its parasites. The aim of this study is to provide better knowledge and understanding on the occurrence of parasites and microbial status of tinfoil barbs from Kenyir Lake. The presence of these organisms in the fish may negate its economic potential and nutritional benefits.

\section{Materials and methods}

\section{Sampling and Dissecting of Barbonymus schwanenfeldii}

A total of 265 samples of tinfoil barbs were caught alive using gill nets from upstream of Tembat $\left(\mathrm{N} 05^{\circ} 12.715^{\prime}, \quad \mathrm{E} 102^{\circ} 38.435^{\prime}\right)$ and Petuang (N05 $\left.12.469^{\prime}, \mathrm{E} 102^{\circ} 39.379^{\prime}\right)$ rivers, which flowed into Kenyir Lake (Figure 1). Fish species were identified by their morphological characteristics. All samples were placed in a 50 litre aquarium with continuous oxygen supply generated from portable aerators (JAD D-200, Guangdong, China). The pithing technique was used to paralyze the fishes. Once paralyzed, the fishes were cut from the anus towards the gill along the ventral side to remove the stomach and intestines. The stomach and intestines were placed in a petri dish with drops of distilled water. These organs were then carefully dissected for nematodes. The dissection was conducted using a Nikon dissecting microscope (Leica EZ4, China). 


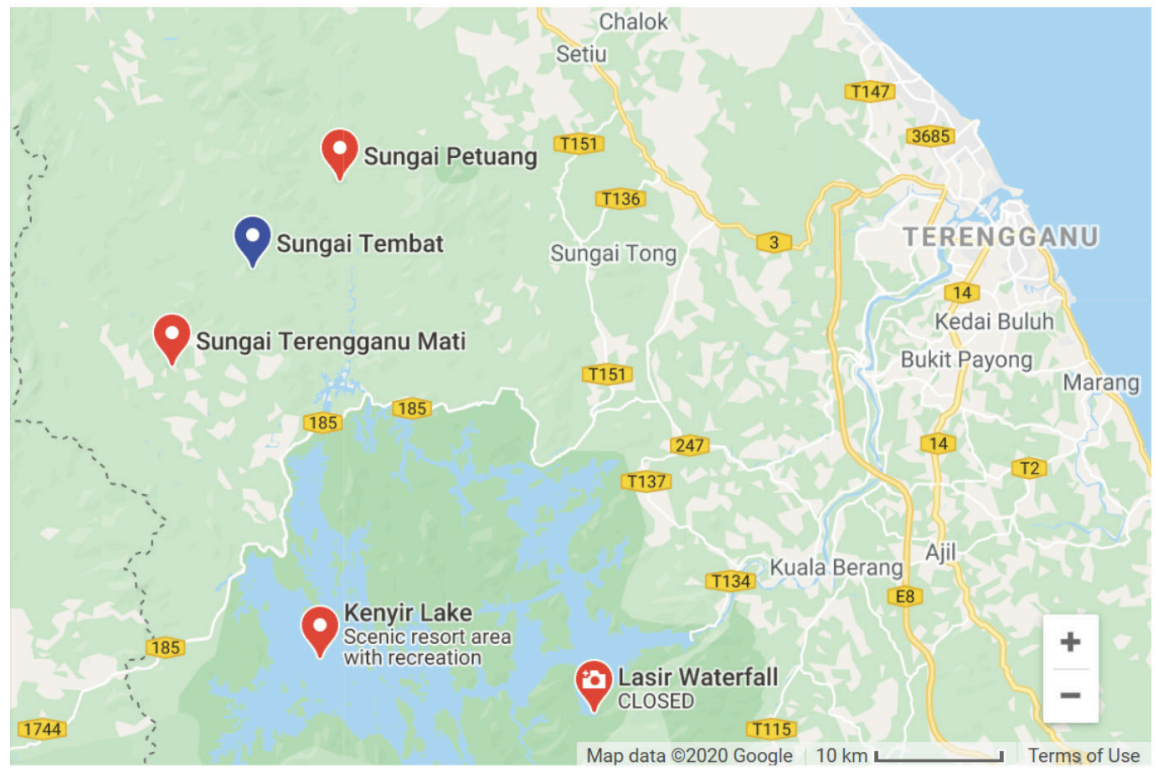

Figure 1: Kenyir Lake is located between latitude $4^{\circ} 40^{\prime} \mathrm{N}$ to $5^{\circ} 15^{\prime} \mathrm{N}$ and longitudes $102^{\circ} 32^{\prime} \mathrm{E}$ to $102^{\circ} 55^{\prime} \mathrm{E}$. Precisely, Tembat river is situated at latitude $\mathrm{N} 05^{\circ} 12.715^{\prime}$ longtitude E102 $38.435^{\prime}$ and Petuang river is situated at latitude $\mathrm{N} 05^{\circ} 12.469^{\prime}$ longtitude $\mathrm{E} 102^{\circ} 39.379^{\prime}$

Source date: Google map Retrieved on 25th April 2020

\section{Nematode Identification}

Nematodes collected from the fish stomach and intestine were placed in cavity blocks containing distilled water to wash away food particles or mucus. The number of nematodes collected from each fish was recorded before they were preserved in a bijou bottle containing $70 \%$ alcohol. Nematodes were placed on a slide and several drops of lactophenol were placed on the specimen to highlight the internal structure for morphological identification using a light microscope (Leica DM750, Heerbrugg, Switzerland). The identification of nematodes was based on the morphology of their external and internal structures using identification keys (Yamaguti, 1961; Skryabin, 1992).

\section{Prevalence and Mean Intensity of Nematode Infection}

Epidemiological characteristics - the prevalence and mean intensity of nematodes in the fish - were determined according to Margolis et al., (1982) and Bush et al., (1997). Prevalence was defined as the percentage of fish infected with parasites from total number of fish studied (Equation 1). Mean intensity was the quantity of parasitic individuals found in the total number of infected fish that were caught, and was calculated for each parasite species identified (Equation 2).

Prevalence $=\frac{\text { Number of fish infected }}{\text { total fish studied }} \times 100 \%$ (Equation 1)

Mean intensity $=\underline{\text { Number of parasite individual found }}$ Number of fish infected

(Equation 2)

\section{Bacteria Count and Identification}

Approximately $10 \pm 0.1 \mathrm{~g}$ of tinfoil barb muscle was placed into a sterile filter bag containing $90 \mathrm{ml}$ of Maximum Recovery Diluent (MRD) (MERCK, Darmdstadt, Germany) before being homogenized (Interscience, Saint Nom la Brétèche, France). A serial dilution was carried out before spreading the samples on plate count agar (PCA) and incubated at $30^{\circ} \mathrm{C}$ for 48 hours. Microbiological counts were expressed as log colony forming units per gram of samples 
$\left(\log _{10} \mathrm{CFU} \mathrm{g} \mathrm{g}^{-1}\right)$. Nematodes were washed five times with physiological saline before soaking with oxytetracycline antibiotics (Wood, 1998) for five minutes and rinsed with physiological saline. Parasites were homogenized with MRD in a microtube. A serial dilution was carried out before spreading the sample on plate count agar (PCA) and incubated at $30^{\circ} \mathrm{C}$ for 48 hours.

Bacteria identification was performed on samples infected by the nematodes. A minimum of 20 isolates were randomly selected using a Harrison Disc (Harrigan, 1998). The isolates were streaked onto PCA and incubated at $30^{\circ} \mathrm{C}$ for $24 \mathrm{~h}$. The size and colour of the colonies were recorded and the following tests were carried out; Gram reaction, catalase activity, oxidase activity (Harrigan, 1998) and indole test. The isolates were suspended in BBL inoculum fluid before being inoculated in a substrate panel of the BBL Crystal Rapid Gram Positive ID and BBL Crystal Enteric/Nonfermenter ID system. The substrate panels were incubated at $35^{\circ} \mathrm{C}$ for $24 \mathrm{~h}$ before the bacteria were identified using the BBL Crystal ${ }^{\mathrm{TM}}$ autoreader (Becton Dickinson, New Jersey, USA).

The bacteria identification in nematodes and water samples were performed using the VITEK 2 GN ID Card (BioMérieux, Marcy l'Etoile, France).. Using sterile cotton swabs, a homogenous suspension was prepared by transferring a single colony from the nutrient agar to $3 \mathrm{ml}$ of sterile saline in a test tube that contained 0.45 to $0.50 \mathrm{NaCl}$ with a $\mathrm{pH}$ between 4.5 and 7. The test tube was vortexed thoroughly. The inoculum density was adjusted to MacFarland unit standard between 0.5 and 0.63 using the DensiCheck Plus optical density measuring instrument (BioMérieux, Marcy l'Etoile, France). Before the package linear was opened, the card should be place at room temperature. Next, the VITEK Card was inserted into the compact cassette with the prepared homogenous suspension and the data was ready to be read. The results were analysed by using the VITEK 2 Compact System (BioMérieux, Marcy l'Etoile, France).

\section{Statistical Analysis}

All the experiments were carried out in triplicates and the data were presented as mean \pm standard deviation. All data were statistically analysed using IBM SPSS Version 20 (IBM Corporation, New York, USA).

\section{Result and Discussion}

\section{Nematode identification, prevalence and mean intensity}

The identification of fish species was based on the length and shape of the spicules on the position of the excretory pore, number and arrangement of caudal papillae (Timi \& Lanfranchi, 2006). The appearance of the mouth perpendicular to the body axis, the absence of an intestinal caecum, and the presence of sclerotized plaques in the pseudo-buccal capsule with Y-shaped suture were the most important features to allocate a nematode within the genus Cucullanus sp. The genus of Cucullanus sp. that infected tinfoil barbs from Kenyir Lake was categorized under the family Cucullanidae. The prevalence of nematode infection in tinfoil barbs from Tembat river was $3.59 \%$. The mean intensity was recorded at 12.67 per fish. Meanwhile, the prevalence of nematode infection in tinfoil barbs from Petuang river was calculated at $1.02 \%$, with a mean intensity of 7.00 per fish (Table 1).

An early recovery study of Cucullanus sp. was reported by Caspeta-Masdujano et al., (2000), where they were found in the intestines of freshwater catfish Rhamdia guatemalensis (Gunther) (Pisces, Pimelodidae) in the brooks of El Saltillo, Valle Nacional and San Juan Bautista in Mexico. Nnadi (2012) reported that Cucullanus sp. were found in African sharptooth catfish (Clarias gariepinus) caught from two natural water systems - the Otamiri and Nworie rivers in Nigeria. Nematodes were very distinct in shape, large and visible to the naked eye. Bakaria et al., (2018) stated that Cucullanus sp. was found in European eel (Anguilla Anguilla) in Tonga Lake, Nigeria. However, they added that the prevalence and mean intensity were 
Table 1: The prevalence and mean intensity of nematodes found in tinfoil barb from Tembat and Petuang rivers in Kenyir Lake, Terengganu, Malaysia

\begin{tabular}{lccccc}
\hline Sampling location & $\begin{array}{c}\text { Number of } \\
\text { fish examined }\end{array}$ & $\begin{array}{c}\text { Number of } \\
\text { fish infected }\end{array}$ & $\begin{array}{c}\text { Number of } \\
\text { nematodes }\end{array}$ & $\begin{array}{c}\text { Prevalence } \\
\text { (\%) }\end{array}$ & $\begin{array}{c}\text { Mean } \\
\text { intensity (per } \\
\text { fish) }\end{array}$ \\
\hline Tembat & 167 & 6 & 76 & 3.59 & 12.67 \\
Petuang & 98 & 1 & 7 & 1.02 & 7.00 \\
\hline
\end{tabular}

recorded at $0.3 \%$ and one per fish, respectively, which was the lowest value for a parasite species found in fish of Tonga Lake. On the other hand, Pereira et al. (2018) found a $2.08 \%$ prevalence of Cucullanus sp. infestation in long-whiskered catfish (Sorubin lima) caught in the Amambai river in Brazil, which was a new parasite record for this host. These observations also indicated that Cuculanus sp. had low parasitic specificity.

A various research had documented that the nematode genus Cucullanus Muller, 1777 (Cucullanidae) was the dominating variant, not only in freshwater, but also in brackish and marine waters around the world. Morales-Serna et al. (2019) recently documented that Cucullanus sp. had prevalence of $14 \%$ and mean intensity of 1.9 in the intestines of the Yucatan molly (Poecilia velifera) caught in the wetlands of Terminos Lagoon, Mexico. Morever, Al-Zubaidy et al. (2012) reported that Cucullanus sp. was also found in marine species, like the blackspot snapper (Lutjanus fulviflamma), humpback red snapper (L. gibbus) and crimson jobfish (Pristipomoides filamentosus), with prevalences of 5.0, 10.0 and $16.7 \%$, respectively. All his samples were harvested from the Red Sea off
Yemen. In addition, Moravec \& Justine (2018) stated that three new species of Cucullanus sp. were obtained in the digestive tract of deepwater fishes like the longfin African conger (Conger cinereus), lipspot moray (Gymnothorax chilospilus) and seabream (Dentex fourmanoiri) collected from New Caledonia. To the best of our knowledge, the present study represented the first record of Cucullanus sp. on B.schwanefeldii collected from Kenyir Lake.

\section{Bacteria count and identification}

The total bacteria count in Cucullanus sp. of tinfoil barbs from Tembat river was recorded at $4.56 \pm 0.49 \log _{10} \mathrm{CFU} \mathrm{g}^{-1}$, which was significantly $(p<0.05)$ higher compared to the bacterial count in muscles of non-infected and infected fish, besides the water samples (Table 2). The total bacteria count in non-infected tinfoil barbs of Petuang river was higher, but not significantly different ( $p>0.05$ ) from the count in the muscles of infected fish and nematode itself. In addition, the total bacteria count in water samples of Petuang river was significantly $(\mathrm{p}<0.05)$ lower compared to the bacteria found in non-infected tinfoil barbs (Table 2).

Table 2: Total bacteria count in muscle of Barbonymus schwanenfeldii, nematode and water samples from Tembat and Petuang rivers, Kenyir Lake, Terengganu

\begin{tabular}{lcccc}
\hline $\begin{array}{c}\text { Sampling } \\
\text { location }\end{array}$ & $\begin{array}{c}\text { Bacteria count in fish } \\
\text { muscle }\end{array}$ & $\begin{array}{c}\text { Bacteria } \\
\text { count in } \\
\text { parasite } \\
\text { Nonfected }\end{array}$ & $\begin{array}{c}\text { Parasite } \\
\text { infected }\end{array}$ & $\begin{array}{c}\text { Bacteria } \\
\text { count } \\
\text { in water } \\
\text { sample }\end{array}$ \\
\hline Tembat & $3.34 \pm 0.17^{\mathrm{a}}$ & $3.56 \pm 0.04^{\mathrm{a}, \mathrm{b}}$ & $4.56 \pm 0.49^{\mathrm{c}}$ & $3.23 \pm 0.16^{\mathrm{a}}$ \\
Petuang & $4.03 \pm 0.05^{\mathrm{b}, \mathrm{c}}$ & $3.52 \pm 0.06^{\mathrm{a}, \mathrm{b}}$ & $3.61 \pm 0.26^{\mathrm{a}, \mathrm{b}}$ & $3.01 \pm 0.15^{\mathrm{a}}$ \\
\hline
\end{tabular}

The values are mean \pm standard deviation. Different letters a,b,c in the same row, indicate statistically significant differences $(\mathrm{p}<0.05)$ among the samples. 
The muscles of infected tinfoil barb caught from Tembat river were dominated by two species of bacteria; Corynebacterium bovis and Weeksella virosa/Bergeyella zoohelcum. Meanwhile, Acinobacter lwoffii was found abundantly in Cucullanus sp. of tinfoil barbs collected from Tembat river. In addition, Pseudomonas fluorescens and Acinobacter lwoffii were identified in the muscles of infected tinfoil barbs collected from Petuang river. Pseudomonas oryzihabitans was found in the nematodes of tinfoil barbs caught from Petuang river. Streptococcus thoraltensis and Enterobacter amnigenus were identified in water samples of Tembat and Petuang rivers, respectively (Table 3).

The bacteria in infected tinfoil barb muscles were predominantly Weeksella/Bergeyella spp., Weeksella virosa (formerly known as CDC Group IIf) and Bergeyella zoohelcum (formerly known as CDC Group IIj), which all belonged to the family of Flavobacteriaceae (Bernardet et al., 1996). The bacterias were characterised as short to moderately-long rods, with parallel or slightly irregular sides, and rounded or slightly tapered ends. They were usually 0.3 to $0.6 \mu \mathrm{m}$ wide and 1 to $10 \mu \mathrm{m}$ long (Jooste \& Hugo., 1999). These strains were Gram negative, nonspore forming, without flagellas, non-motile and non-pigmented (Jooste \& Hugo, 1999). But most did contain a non-diffusible yellowish to orange pigment due to the presence of carotenoid and/or flexirubin (Loch \& Faisal, 2015).

Weeksella/Bergeyella spp. thrived in aerobic conditions, where their oxidase and catalase activities were common (Table 3). They were considered as spoilage bacteria (Hugo et al., 2006) because of their capability to utilize lipases to degrade the quality of fish. Correspondingly, Engelbrecht et al. (1996) had documented Weeksella/Bergeyella spp. being associated with the production of stale or pungent odour in fish. Hugo et al. (2006) emphasized that Weeksella/Bergeyella were not free living bacterias, but had no pathogenic role.

Acinobacter lwoffi were found in both nematode (of Tembat river) and muscle of tinfoil barbs (of Petuang river). Acinobacter spp. are Gram negative aerobic bacillus microbes commonly found in water and predominantly isolated from spoiled fish (Kamfer, 2000). Betts (2006) stated that the sensory scores were acceptable and volatile compounds were lower even though Acinetobacter is present. Lakshamanan et al., (2002) documented that Acinetobacter spp. was the predominant amine-forming bacteria of fish in ice storage. However, histamine intoxication had never been reported in freshwater fish. Therefore, these studies suggested that Pseudomonas spp. and Acinetobacter spp. were a part of the microflora in freshwater fish, but had potential to spoil the fish during storage.

Pseudomonas sp. inhabited both the muscle of infected tinfoil barbs and nematodes from Petuang river (Table 3). Pseudomonas sp. is a Gram negative and non-spore-forming rod bacterium, and is mostly aerobic and motile with a polar flagella. P. fluorescens and P. oryzihabitans showed a positive oxidase and catalase activity (Table 3). Pseudomonas sp. were reported as the dominant bacteria that caused spoilage in fish by secreting lipases and proteases that cause the formation of sulphides and trimethylamine (TMA) on the fish, and also by causing the fish to become slimy (Hozbor et al., 2006; Doyle, 2007; Adebayo-Tayo et al., 2012d). Various researchers had also found Pseudomonas spp. to be responsible for food spoilage during periods of storage (Koutsoumanis \& Nychas, 1999; Hazbor et al., 2006; Adebayo-Tayo et al., 2012d; Milne \& Powell, 2014).

The family Enterobacteriaceae comprised 34 genera, 149 species and 21 subspecies. These included Enterobacter amnigenus that were found in the water samples of Petuang river (Table 3). These bacteria were Gram negative and non-spore-forming, with a typical size at 0.3$1.8 \mu \mathrm{m}$, and straight rod shape (Table 3). Baylis (2006) stated that Enterobacteriaceae were dominant spoilage microorganisms at above $10^{\circ} \mathrm{C}$ storage, where it was capable of reducing trimethylamine N-oxide to TMA assisted by hydrogen produced from fermentation (Strom \& Larsen, 1979). 
Table 3: Bacteria identified in muscles of Barbonymus schwanenfeldii, nematodes and water samples from Tembat and Petuang rivers, Kenyir Lake, Terengganu

\begin{tabular}{|c|c|c|c|c|c|c|c|}
\hline \multicolumn{2}{|c|}{ Sampling location } & \multirow{2}{*}{$\begin{array}{l}\text { Characteristic } \\
\begin{array}{l}\text { Yellow, large, } \\
\text { coccus }\end{array}\end{array}$} & \multirow{2}{*}{$\begin{array}{c}\begin{array}{c}\text { Gram } \\
\text { reaction }\end{array} \\
+\end{array}$} & \multirow{2}{*}{$\begin{array}{c}\begin{array}{c}\text { Oxidase } \\
\text { reaction }\end{array} \\
-\end{array}$} & \multirow{2}{*}{$\begin{array}{c}\text { Catalase } \\
\frac{}{+}\end{array}$} & \multirow{2}{*}{ Indole } & \multirow{2}{*}{\begin{tabular}{l}
\multicolumn{1}{c}{$\begin{array}{c}\text { Bacteria } \\
\text { Identification }\end{array}$} \\
$\begin{array}{l}\text { Corynebacterium } \\
\text { bovis }\end{array}$
\end{tabular}} \\
\hline Tembat & $\begin{array}{l}\text { Muscle of } \\
\text { parasite }\end{array}$ & & & & & & \\
\hline & & $\begin{array}{l}\text { Yellow, small, } \\
\text { rod }\end{array}$ & - & + & + & + & $\begin{array}{l}\text { Weeksella virosal } \\
\text { Beryella zoohelcum } \\
(97 \%)\end{array}$ \\
\hline & Nematode & White, rod & - & - & + & - & $\begin{array}{l}\text { Acinobacter lwoffii } \\
(99 \%)\end{array}$ \\
\hline & $\begin{array}{l}\text { Water } \\
\text { sample }\end{array}$ & White, coccus & + & - & - & + & $\begin{array}{l}\text { Streptococcus } \\
\text { thoraltensis (98\%) }\end{array}$ \\
\hline \multirow[t]{4}{*}{ Petuang } & \multirow{2}{*}{$\begin{array}{l}\text { Muscle of } \\
\text { parasite } \\
\text { infected }\end{array}$} & $\begin{array}{l}\text { White, small, } \\
\text { rod }\end{array}$ & - & + & + & - & $\begin{array}{l}\text { Pseudomonas } \\
\text { fluorescens }\end{array}$ \\
\hline & & White, cocci & - & - & + & - & $\begin{array}{l}\text { Acinobacter lwoffii } \\
(99 \%)\end{array}$ \\
\hline & Nematode & Yellow, rod & - & + & + & - & $\begin{array}{l}\text { Pseudomonas } \\
\text { oryzihabitans } \\
(91 \%)\end{array}$ \\
\hline & $\begin{array}{l}\text { Water } \\
\text { sample }\end{array}$ & White, cocci & - & - & + & - & $\begin{array}{l}\text { Enterobacter } \\
\text { amnigenus (99\%) }\end{array}$ \\
\hline
\end{tabular}

\section{Conclusion}

The prevalence and mean intensity of Cucullanus sp. in tinfoil barbs were different between Tembat and Petuang rivers near Kenyir Lake, where both were higher in the former river. The microbiology quality was not significantly influenced by the prevalence and mean intensity of parasite infection. Pseudomonas sp., Acinobacter sp. and Weeksella/Beryella $\mathrm{sp}$. were predominantly found in both muscle of tinfoil barbs infected by the Cuculanus sp. and in the nematode itself. Stilwell et al. (2018) documented that microbes might form symbiotic; mutualism (all partners benefit); or, parasitc (some partners benefit but other was harmed or killed) relationships with their host. These relationships, however, depended on the host identity, abiotic parameters and microbial community partners that determined whether they were beneficial to the hosts' health, development and nutrition potential.

With low and insignificant bacterial count in nematodes and tinfoil barbs, recent studies had concluded that the microbes had formed a mutual relationship with both hosts (nematode and fish). These common freshwater bacteria were more likely to influence fish quality during storage. Concisely, the presence of these microorganisms and Cucullanus sp. in tinfoil barbs in the rivers of Kenyir Lake was not alarming. However, further investigative approaches would be suggested, including the "omics" for symbiosis theory.

\section{Acknowledgements}

The authors extend their gratitude to reviewers for critical comments on the manuscript and the university for the research opportunity. 


\section{References}

Adebayo-Tayo, B. C., Odu, N. N., Igiwiloh, N. J. P. N., \& Okonko, I. O. (2012d). Microbiological and physicochemical level of fresh catfish (Arius hendelotic) from different markets in Akwa Ibom State, Nigeria. New York Science Journal, 5(4), 46-52.

Al-Zubaidy, A. B., Mhaisen, F. T., \& Abker, A. M. (2012). Occurrence of five nematode species from some Red Sea fishes, Yemen. Mesopotamian Journal of Marine Science, 27(2), 140-156.

Bakaria, F., Belhaoues, S., Djebbari, N., Tahri, M., Ladjama, I., \& Bendaad, L. (2018). Metazoan parasites and health state of European eel, Anguilla Anguilla (Anguilliformes, Anguillidae) from Tonga Lake and El Mellaah Lagoon in the northest of Algeria. Vestnik Zoologii, 52(4), 279288.

Barber, I. (2007). Parasites, behaviour and welfare in fish. Applied Animal Behaviour Science, 104, 251-264.

Baylis, C. L. (2006). Enerobacteriaceae. In Balckburn, C. W. (Ed.), Food spoilage microorganism (pp 624-664). England, United Kingdom: Woodhead Publishing Ltd.

Betts, G. (2006). Other spoilage bacteria. In C. W., Blackburn (Ed.), Food spoilage microorganisms (pp. 668-695). Cambridge, United Kingdom: Woodhead Publishing Limited.

Bush, A., Lafferty, K., Lotz, J., \& Shostak, A. (1997). Parasitology meets ecology on its own terms: Margolis et al. Revisited. The Journal of Parasitology, 83(4), 575-583.

Caspeta-Mandujano, J. M., Moravec, F., \& Aguilar-Aguilar, R. (2000). Cucullanus mexicanus sp.n (Nematoda: Cucullanidae) from the intestine of the freshwater catfish Rhamdia guatemalensis (Pimelodidae) in Mexico. Helminthologia, 37(4), 215-217.
Chong, V. C., Lee, P. K., \& Lau, C. M. (2010). Diversity, extinction risk and conservation of Malaysian fishes. Journal of Fish Biology, 76(9), 2009-2066.

Department of Fisheries (Malaysia). (2019). Jadual Perikanan Darat Portal Rasmi Jabatan Perikanan Malaysia Kementerian Pertanian and Industri Asas Tani. https://www.dof. gov.my/index.php/pages/view/3754

Doyle, E. M. (2007). Microbial food spoilagelosses and control strategies. A brief review of the literature. Food Research Institute, University of Wisconsin-Madison. http://fri. wisc.edu/docs/pdf/FRI_Brief_Microbial_F ood_Spoilage_7_07.pdf

Engelbrecht, K., Jooste, P. J., \& Prior, B. A. (1996). Spoilage characteristics of Gramnegative genera and species isolated from Cape marine fish. South African Journal of Clinical Nutrition, 8, 66-71.

Harrigan, W. F. (1998). Sampling methods for the selection and examination of microbial colonies. In Harrigan, W. (Ed.), Laboratory methods in food microbiology ( pp 532). London, United Kingdom: Academic Press Ltd.

Hozbor, M. C., Saiz, A. I., Yeannes, M. I., \& Fritz, R. (2006). Microbiological changes and its correlation with quality indices during aerobic iced storage of sea salmon (Pseudopercis semifasciata). LWT - Food Science and Technology, 39(2), 99-104.

Hugo, C. J., Bruun, B., \& Jooste, P. J. (2006). The genera Bergeyella and Weeksella. In Dworkin, M., Falkow, S., Rosenberg, E., Schleifer, K-H., \& Stackerbrandt, E. (Eds.), The prokaryotes (pp 532-538). Singapore: Springer.

Ismail, N. I. A., Amal, M. N. A., Shohaimi, S., Saad, M. Z. S., \& Abdullah, S. Z. (2016). Associations of water quality and bacterial presence in cage cultured red hybrid tilapia, Oreochromis nimoticus X O. mossambicus. Aquaculture Reports, 4, 57-65. 
Jooste, P. J., \& Hugo, C. J. (1999). The taxonomy, ecology and cultivation of bacterial genera belonging to the family Flavobacteriaceae. International Journal of Food Microbiology, 53, 81-94.

Kamaruddin, I. S., Mustafa Kamal, A. S., Christianus, A., Daud, S. K., \& Yu-Abit, L. (2011). Fish community in Pengkalan Gawi-Pulau Dula Section of Kenyir Lake, Terengganu, Malaysia. Journal of Sustainability Science and Management, 6, 89-97.

Kampfer, P. (2000). Acinetobacter. In Robinson, R. K., Batt, C. A., \& Patel, P. D. (Eds.), Encyclopaedia of food microbiology. Volume 1 (pp 7-15). London, United Kingdom: Academic Press.

Koutsoumanis, K., \& Nychas, G. J. E. (1999).

Chemical and sensory changes associated with microbial flora of Mediterranean boque (Boops boops) stored aerobically at $0,3,7$, and $10^{\circ} \mathrm{C}$. Applied Environmental Microbiology, 65, 698-706.

Lakshmanan, R., Shakila R. J., \& Jeyasekaran, G. (2002). Survival of amine-forming bacteria during the ice storage of fish and shrimp. Food Microbiology, 19, 617-625.

Lemly, A. D., \& Esch, G. W. (1984). Effects of the trematode Uvulifer ambloplitis on juvenile bluegill sunfish, Lepomis macrochirus: Ecological implications. Journal of Parasitology, 70, 475-492.

Loach, T. P., \& Faisal, M. (2015). Emerging flavobacterial infections in fish: A review. Journal of Advanced Research, 6, 283-300.

Marcel, G., Sabri, M. Y., Siti-Zaharah, A., \& Emikpe, B. O. (2013). Water condition and identification of potential pathogenic bacteria from red tilapia reared in cage culture system in two different water bodies in Malaysia. African Journal of Microbiology Research, 7(47), 5330-5337.

Marcogliese, D. J. (2002). Food webs and the transmission of parasites to marine fish. Parasitology, 124, S83-S99.
Margolis, L., Esch, G., Holmes, J., Kuris, A., \& Schad, G. (1982). The use of ecological terms in parasitology (Report of an Ad Hoc Committee of the American Society of Parasitologists). The Journal of Parasitology, 68(1), 131-133.

Milne, D., \& Powell. S. M. (2014). Limited microbial growth in Atlantic salmon packed in a modified atmosphere. Food Control, 42, 29-33.

Morales-Serna, F. N., Rodrigues-Santiago, M. A., Gelabert, R., \& Flores-Morales, L. M. (2019). Parasites of fish Poecilia velifera and their potential as bioindicators of wetland restoration progress. Helgoland Marine Research, 73, 1-8.

Moraves, F., \& Justine, J. L. (2018). Three new species of Cucullanus (Nematoda: Cucullanidae) from marine fishes off New Caledonia, with a key to species of Cucullanus from Aguilliformes. Parasite, 25, 1-15.

Newton, R. J., Jones, S. E., Eiler, A., MacMohan, K. D., \& Bertilson, S. (2011). A guide to the natural history of freshwater lake bacteria. Microbiology and Molecular Biology Reviews, 75(1), 14-49.

Nnadi, E. I. (2012). A study of parasitic infections of Clarias gariepinus in natural waters of Owerri, Imo State, Nigeria. International Journal of Agriculture and Rural Development, 15(2), 976-981.

Osnin, N. A., \& Abdul Rahman, N. S. F. (2018). Assessment and ranking of inland navigation practices in Malaysia: The case of Kenyir Lake. The Asian Journal of Shipping and Logistics, 34(4), 289-296.

Pereira, E. S., Mauad, J. R. C., Takemoto, R. M., \& Lima-Junior, S. E. (2018). Fish parasite diversity in the Amambai River, State Mato Grosso do Sul, Brazil. Acta Scientiarum Biological Sciences, 40, 1-7.

Rouf, A. J. M. A., Ambak, M. A., Shamsudin, L., Siew-Moi, P., \& Ho, S. C. (2008). Temporal changes in the periphytic algal 
communities in a drowned tropical forest reservoir in Malaysia: Lake Kenyir. Lakes and Reservoir: Research and Management, 13, 271-287.

Santoro, M., Mattiucci, S., Work, T., Cimmaruta, R., Nardi, V., Cipriani, P., Bellisario, B., \& Nascetti, G. (2013). Parasitic infection by larval helminths in Antarctic fishes: Pathological changes and impact on the host body condition index. Diseases of Aquatic Organisms, 105, 139-148.

Seesao, Y., Gay, M., Merlin, S., Aliout-Denis, C. M., \& Audebert, C. (2017). A review of methods for nematode identification. Journal of Microbiological Methods, 138, 37-49.

Shaharom, F. (2012). Fish parasites of Lake Kenyir, Peninsular Malaysia. (Ed). (pp 141). Kuala Terengganu, Terengganu: Penerbit Universiti Malaysia Terengganu.

Skryabin, K. I. (1992). Key to parasitic nematode: Camallanata, Rhabditata, Tylenchata, Tricephalata, Dioctophymata and distribution of parasitic nematodes in different hosts. (Ed) (pp1109). Leiden: Brill Academy.

Stilwell, M. D., Cao, M., Goodrich-Blair, H., \& Weibel, D. B. (2018). Studying the symbiotic bacterium Xenorhabdus nematophila in individual, living Steinema caarpocapsae Nematodes using microfluidic systems. MSphere, 3(1), 1-17.

Strom, A. R., \& Larsen, H. (1979). Anaerobic fish spoilage by bacteria. I. Biochemical changes in herring extracts. Journal of Applied Bacteriology, 46, 531-543.
Szekely, C., Shaharom, F., Cech, G., Mohamed, K., Mohd Zin, N. A., Borkhanuddin, M. H. Ostoros, G., \& Molnar, K. (2012). Myxozoan infection of the Malaysian Mahseer, Tor tombroides of Tasik Kenyir reservoir, Malaysia: Description of a new species Myxobolus tambroides sp.n. Parasitology Research, 111, 1749-1756.

Székely, C. S., Shaharom-Harrison, F., Cech, G., Ostoros, G., \& Molnár, K. (2009). Myxozoan infections in fishes of the Tasik Kenyir Water Reservoir, Terengganu, Malaysia. Disease of Aquatic Organisms, $83,37-48$.

Timi, J. T., \& Lanfranchi, A. L. (2006). A new species of Cucullanus (Nematoda: Cucullanidae) parasitizing Conger orbignianus (Pisces: Congridae) from Argentinean waters. Journal of Parasitology, 92, 151-154.

Tonguthai, K. (1997). Control of freshwater fish parasite: A Southeast Asian perspectives. International Journal for Parasitology, 27, 1185-1191.

Wood, M. (1998). The politicization of antimicrobial resistance. Current Opinion in Infectious Diseases, 11, 649-651.

Yamaguti, S. (1961). Systema Helminthum. Vol. (III). The Nematode Vertebrates Part I and II. (ed) (pp1261). New York: Interscience Publishers.

Zulkafli A. R., \& Ashhar, A. O. (2000). Fish fauna in Tasik Kenyir. Freshwater Fisheries Research Centre, Batu Berendam, Melaka. www.fri.gov.my/pppat/kenyirweb/index. html. 